\section{Macro- and Microelement Fertilizers Influence the Severity of Fusarium Crown and Root Rot of Tomato in a Soilless Production System}

\author{
B.K. Duffy and G. Défago \\ Phytopathology Group, Institute of Plant Sciences, Swiss Federal Institute of \\ Technology, Universitätstrasse 2, CH-8092 Zürich, Switzerland \\ Additional index words. Fusarium oxysporum f.sp. radicis-lycopersici, hydroponics, \\ Lycopersicon esculentum, root disease, nutrition
}

\begin{abstract}
Host nutritional variables were evaluated for their effects on the severity of crown and root rot of tomato caused by Fusarium oxysporum f.sp. radicis-lycopersici. Tomato (Lycopersicon esculentum Mill.) seedlings (cv. Bonnie Best) were grown in a pathogeninfested, soilless rockwool system in the greenhouse and were fertilized with a nutrient solution that was amended with macro- and microelements at various rates. Disease was evaluated after 2 weeks using an index of 0 to 4 , and plant fresh weight was measured. Regression analysis indicated that disease severity was significantly increased by ammonium-nitrogen $\left[\mathrm{NH}_{4} \mathrm{Cl},\left(\mathrm{NH}_{4}\right)_{6} \mathrm{Mo}_{7} \mathrm{O}_{24}\right.$, and $\left.\left(\mathrm{NH}_{4}\right)_{2} \mathrm{SO}_{4}\right], \mathrm{NaH}_{2} \mathrm{PO}_{4} \cdot \mathrm{H}_{2} \mathrm{O}$, Fe-EDDHA, $\mathrm{MnSO}_{4}$, $\mathrm{MoO}_{3}$, and $\mathrm{ZnSO}_{4} \cdot 7 \mathrm{H}_{2} \mathrm{O}$. Disease severity was reduced by nitrate-nitrogen $\left[\mathrm{Ca}\left(\mathrm{NO}_{3}\right)_{2} \cdot 4 \mathrm{H}_{2} \mathrm{O}\right]$ and $\mathrm{CuSO}_{4} \cdot \mathrm{H}_{2} \mathrm{O}$. Low rates of $\mathrm{NH}_{4} \mathrm{NO}_{3}\left(39\right.$ to $\left.79 \mathrm{mg} \cdot \mathrm{L}^{-1} \mathrm{~N}\right)$ reduced disease, but rates above $100 \mathrm{mg} \cdot \mathrm{L}^{-1} \mathrm{~N}$ increased it. Disease was not affected by $\mathrm{MgSO}_{4} \cdot 7 \mathrm{H}_{2} \mathrm{O}$. In all cases, plant growth was inversely related to disease severity. Mineral fertilizers had no effect on nutrient solution $\mathrm{pH}$. This information sheds new light on environmental factors that influence plant-pathogen interactions, and may be applied to develop a management strategy for Fusarium crown and root rot based on host nutrition.
\end{abstract}

Crown and root rot of tomato (also referred to as foot and root rot) caused by Fusarium oxysporum Schlechtend.:Fr. f.sp. radicislycopersici Jarvis \& Shoemaker was first described in Japan in the late 1970s, and has since become an economically important problem in greenhouse tomato production throughout Europe, North America, Japan, and Israel (Jarvis, 1988). It is considered the most destructive tomato disease caused by a nonzoosporic pathogen in soilless hydroponics production systems, where reductions in marketable yield can exceed 60\% (Mihuta-Grimm et al., 1990; Stanghellini and Rasmussen, 1994). Tomato plants can be infected at any time, but losses are especially severe when infection occurs at the seedling stage. Symptoms include dark brown necrotic lesions that form on the roots and crown region and may extend up the hypocotyl, stem, and foliage; localized discoloration of the vascular tissues; and subsequent leaf chlorosis, wilting, and death. The pathogen is spread via infected

Received for publication 3 Aug. 1998. Accepted for publication 21 Oct. 1998. We thank Barbara Pärli and Ingeborg Kump for technical assistance, Jacques Fuchs and Marcello Zala for valuable advice in developing the disease assay, and Emmannuel Frossard, ETH Zürich, and David Weller, USDAARS Pullman, Wash., for comments on the manuscript. The cost of publishing this paper was defrayed in part by the payment of page charges. Under postal regulations, this paper therefore must be hereby marked advertisement solely to indicate this fact.

HortScience, Vol. 34(2), April 1999
Jarvis and Thorpe, 1981), but is technically impractical in hydroponic production systems. Alternative control measures are needed, ideally with the aim of developing an integrated disease management strategy.

The nutritional status of a plant has a major impact on disease susceptibility, and this has been exploited for suppressing a variety of diseases (Engelhard, 1989). Notable examples are Fusarium wilts caused by $F$. oxysporum formae speciali, with reports dating to the 1920s that describe the beneficial effect of lime amendments (Jones et al., 1989). Since then, the effects of most major and minor nutrients on wilt diseases have been studied. Jones and coworkers (Jones et al., 1989) applied this information to develop an effective fertilizer-based management strategy for Fusarium wilt of tomato that is used in commercial production systems in the United States. Similar approaches have been successful for control of Fusarium wilts of other vegetable and ornamental crops (Elmer, 1992; Jones et al., 1989; Schneider, 1985).

In contrast, little is currently known about the influence of plant nutrition on crown and root rot of tomato. Previous studies tested single concentrations of nitrogenous fertilizers and sodium chloride (Jarvis and Thorpe, 1980; Woltz et al., 1992), and did not examine the influence of other potentially critical mineral nutrients, particularly microelements. The objective of our study was to compare the effects of several macro- and microelements (various ammonium- $\mathrm{N}$ sources, nitrate- $\mathrm{N}$, sodium phosphate, iron, molybdenum, and copper-, magnesium-, manganese-, and zincsulfates) on disease severity and growth of tomato seedlings. Mineral nutrients were tested across a range of concentrations to provide more information that can be applied to develop a fertilizer-based management strategy and for integrating mineral fertilizers with other control approaches (e.g., biocontrol) that may be sensitive to mineral levels.

\section{Materials and Methods} require multiple approaches. Only a few resistant cultivars are available (Erb and Rowe, 1992; Heremans, 1996; Sugahara and Sakurai, 1991). Fungicides, including benomyl, captafol, imazalil, thiram, and prochloraz-Mn, provide inconsistent control, leave problematic residues in edible tissues, and are often phytotoxic even when applied at recommended rates, especially on seedlings (Hartman and Fletcher, 1991; Jarvis, 1988, 1992; MihutaGrimm et al., 1990). Biological control utilizing fungal (i.e., Trichoderma harzianum and nonpathogenic Fusarium oxysporum and $F$. solani) and bacterial agents (i.e., Bacillus subtilis and Pseudomonas sp.) typically provides only a moderate level of disease suppression in the greenhouse and field (Bochow et al., 1996; Duffy and Défago, 1997; Hartman and Fletcher, 1991; Louter and Edgington, 1990; M'Piga et al., 1997; Sivan et al., 1987). Allelopathy from lettuce (Lactuca sativa $\mathrm{L}$.) and dandelion (Taraxacum Weber sect. ruderalia sp. Kirschner) residues incorporated into soil provides limited control (Jarvis, 1992;
The influence of various mineral nutrients on Fusarium crown and root rot was evaluated in a noncirculating hydroponics system. Pregerminated $[2-3 \mathrm{~d}$ on $0.85 \%$ water agar (Oxoid, Hampshire, England) at $24{ }^{\circ} \mathrm{C} ; 2-4$ mm-long primary root] tomato seeds $\mathrm{cv}$. Bonnie Best were planted on rockwool cubes $\left(3.5 \mathrm{~cm}^{2}\right.$ diameter $\times 4 \mathrm{~cm}$ deep; one seed per cube; Grodania A/S, Hedehusene, Denmark) in square plastic trays $(5.5 \mathrm{~cm}$ deep). The rockwool was saturated with $800 \mathrm{~mL}$ of dilute (1/4 strength) Knop nutrient solution (Ziegler, 1983) containing (mg $\left.\cdot \mathrm{L}^{-1}\right): \mathrm{Ca}\left(\mathrm{NO}_{3}\right)_{2} \cdot 4 \mathrm{H}_{2} \mathrm{O}$ (250); $\mathrm{KH}_{2} \mathrm{PO}_{4}, \mathrm{KCl}$, and $\mathrm{MgSO}_{4} \cdot 7 \mathrm{H}_{2} \mathrm{O}(62.5$ each); and Fe-EDDHA [ethylenediamine-di $(o$ hydroxyphenyl-acetic acid); Sequestrene 138 Fe, Novartis AG, Basel, Switzerland] (5). Autoclave-sterilized stock solutions of the various minerals tested $\left[\mathrm{Ca}\left(\mathrm{NO}_{3}\right)_{2} \cdot 4 \mathrm{H}_{2} \mathrm{O}\right.$, $\mathrm{CuSO}_{4} \cdot 5 \mathrm{H}_{2} \mathrm{O}, \mathrm{MgSO}_{4} \cdot 7 \mathrm{H}_{2} \mathrm{O}, \mathrm{MnSO}_{4}, \mathrm{MoO}_{3}$, $\mathrm{NaH}_{4} \mathrm{PO}_{4} \cdot \mathrm{H}_{2} \mathrm{O}, \mathrm{NH}_{4} \mathrm{Cl},\left(\mathrm{NH}_{4}\right)_{6} \mathrm{Mo}_{7} \mathrm{O}_{24} \cdot 4 \mathrm{H}_{2} \mathrm{O}$, $\left.\mathrm{NH}_{4} \mathrm{NO}_{3},\left(\mathrm{NH}_{4}\right)_{2} \mathrm{SO}_{4}, \mathrm{ZnSO}_{4} \cdot 7 \mathrm{H}_{2} \mathrm{O}\right]$ were added to the nutrient solution just before use to 
give a range of final concentrations (see Figs. 1-5) and the $\mathrm{pH}$ was measured with a Digitalmeter (Auer Bittmann Soulié AG, Zürich, Switzerland). Prior to saturating the rockwool, the nutrient solution was inoculated with $F$. oxysporum to give $\approx 10^{5}$ microconidia plus mycelial fragments per $\mathrm{mL}$, as previously described (Duffy and Défago, 1997). Mycelial fragments were included because in preliminary experiments, inoculation with microconidia alone resulted in little or no disease. Inoculum was produced by growing the pathogen in $150 \mathrm{~mL}$ of $2 \%$ malt extract broth $(\mathrm{pH}$ 5.5; Oxoid) in 500-mL baffled Erlenmeyer flasks at $24{ }^{\circ} \mathrm{C}$ for $5-7 \mathrm{~d}$ with shaking at 130 $\mathrm{rpm}$. Cultures were centrifuged $(15 \mathrm{~min}$ at $2200 g_{n}$ ) to collect fungal biomass, which was then briefly homogenized in an electric blender immediately before adding to the nutrient solution.

Plants were grown in a growth chamber in the greenhouse with $16 \mathrm{~h}$ light $/ 8 \mathrm{~h}$ darkness, 22 ${ }^{\circ} \mathrm{C}$ day $/ 18{ }^{\circ} \mathrm{C}$ night, and $70 \%$ relative humidity. Lower temperatures are favorable for development of crown and root rot, in contrast with the warmer temperatures $\left(\approx 28^{\circ} \mathrm{C}\right)$ that favor Fusarium wilt (Jones et al., 1991). Millipore-filtered bi-distilled water $(0.05 \mu \mathrm{m}$, Elgastat Ultra High Polishing unit, O. Kleiner AG, Wohlen, Switzerland) was added as needed to maintain a solution level of 1 to 2 $\mathrm{cm}$. Fourteen days after planting, tomato seedlings were carefully removed from the rockwool with the upper $1.5 \mathrm{~cm}$ of the root system attached. They were weighed and disease severity was rated on a scale of 0 to 4 (adapted from Mihuta-Grimm et al., 1990) where $0=$ symptomless; $1=$ slight brown discoloration of the upper root system; $2=$ moderate brown discoloration of two-thirds or less of the upper root system; 3 = extreme brown discoloration of the upper root system and numerous necrotic lesions extending up the crown and stem; and $4=$ seedling dead or nearly so. Representative samples of necrotic tissue were plated onto Komada's selective medium (Komada, 1975) to confirm $F$. oxysporum f.sp.radicis-lycopersici as the cause of symptoms.

Mineral nutrient treatments were used at seven rates, each consisting of three replicates over time with 12 to 20 plants per replicate, and were arranged in a completely randomized design. Data for each mineral nutrient treatment were analyzed separately. Relationships between nutrient rate and disease severity and plant weight were evaluated using regression procedures (SAS Institute, Cary, N.C.). Adjusted regression coefficients, which stabilize to a certain value when an adequate set of variables is included in the model, were derived as an alternative to $r^{2}$, which can be driven to 1 by adding superfluous variables to the model with no real improvement of fit (Littell et al., 1991).

\section{Results and Discussion}

Twelve mineral nutrients were tested separately for their influence on Fusarium crown and root rot. A similar and moderate level of

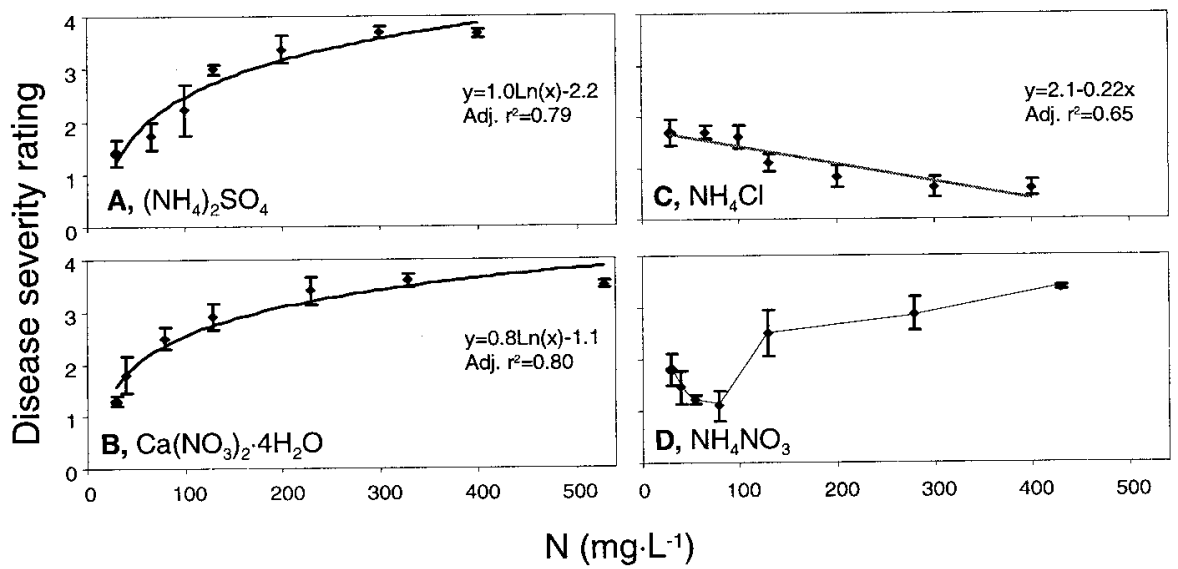

Fig. 1. Influence of the amount and form of nitrogen on Fusarium crown and root rot disease severity after 2 weeks. Nitrogen was supplied at planting as $(\mathbf{A})\left(\mathrm{NH}_{4}\right)_{2} \mathrm{SO}_{4},(\mathbf{B}) \mathrm{Ca}\left(\mathrm{NO}_{3}\right)_{2} \cdot 4 \mathrm{H}_{2} \mathrm{O},(\mathbf{C}) \mathrm{NH}_{4} \mathrm{Cl}$, or $(\mathbf{D})$ $\mathrm{NH}_{4} \mathrm{NO}_{3}$. Values represent the means per plant in three trials. Adjusted regression coefficients and line derivations were significant at $P \leq 0.0001$. Low adjusted $r^{2}$ values for $\mathbf{D}(0.45)$ reflected the different trends at low- and high-N concentrations, and line derivations have not been forced. Vertical bars represent \pm standard error of the mean.

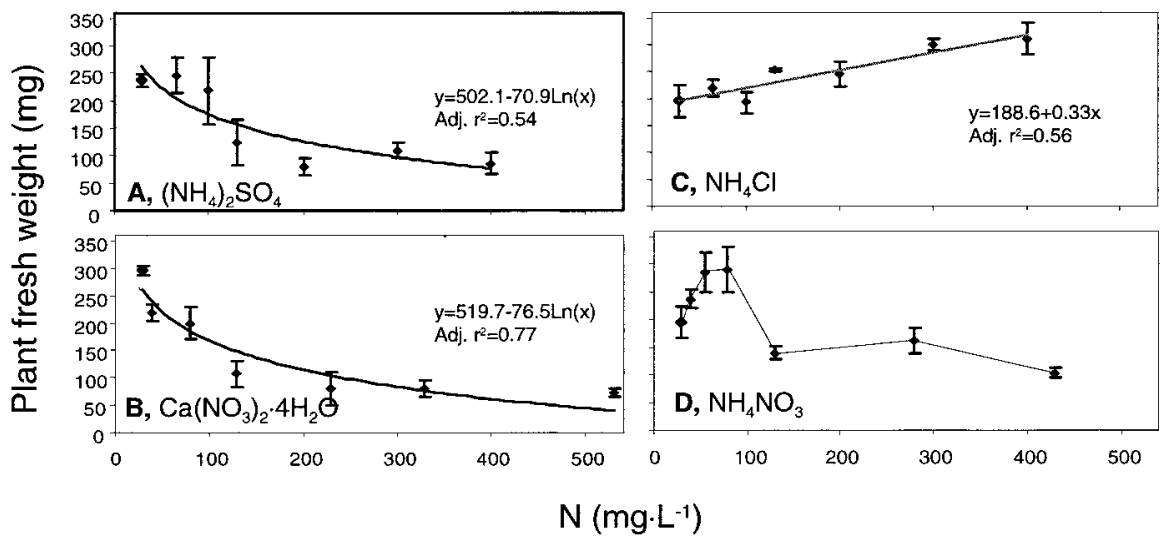

Fig. 2. Influence of the amount and form of nitrogen on growth of Fusarium-infected tomato seedlings after 2 weeks. Nitrogen was supplied at planting as (A) $\left(\mathrm{NH}_{4}\right)_{2} \mathrm{SO}_{4},(\mathbf{B}) \mathrm{Ca}\left(\mathrm{NO}_{3}\right)_{2} \cdot 4 \mathrm{H}_{2} \mathrm{O},(\mathbf{C}) \mathrm{NH}_{4} \mathrm{Cl}$, and (D) $\mathrm{NH}_{4} \mathrm{NO}_{3}$. Values represent the means per plant in three trials. Adjusted regression coefficients and line derivations were significant at $P=0.0001$. Low adjusted $r^{2}$ values for $\mathbf{D}(0.25)$ reflected the different trends at low- and high-N concentrations, and line derivations have not been forced. Vertical bars represent \pm standard error of the mean.
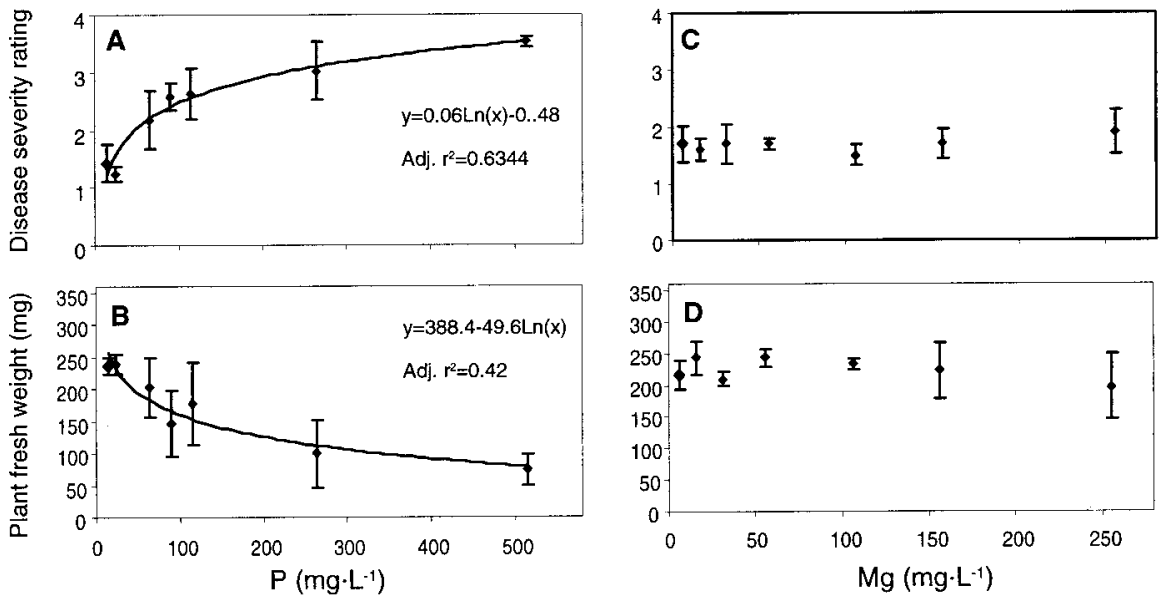

Fig. 3. Influence of sodium phosphate $(\mathbf{A}, \mathbf{B})$ and magnesium sulfate $(\mathbf{C}, \mathbf{D})$ on Fusarium crown and root rot severity and on tomato seedling growth after 2 weeks. Values represent the means per plant in three trials. Adjusted regression coefficients and line derivations in $\mathbf{A}-\mathbf{B}$ were significant at $P \leq 0.0009$. Differences in $\mathbf{C}-\mathbf{D}$ were nonsignificant $(P \geq 0.6000)$. Vertical bars represent \pm standard error of the mean.

disease (1-2 rating on a scale of 4 ) developed in all control treatments that were provided with the standard nutrient solution (no additional minerals) (Figs. 1-4). Disease developed rapidly in affected seedlings, with ne- crotic lesions forming at the crown generally within a week of emergence. This was often followed by severe chlorosis and turgor loss. No signs of vascular infection were observed beyond the area of superficial necrosis. Severe 
disease developed (mean rating 3-4) in treatments provided with ammonium-N (Fig. 1), phosphate (Fig. 3), iron, zinc, manganese, and molybdenum (Fig. 4). At the higher concentrations tested, infected seedlings often failed to emerge. Seedlings with no symptoms after $10 \mathrm{~d}$ usually remained healthy even when left to mature (data not shown), probably because of poor spread of the pathogen in rockwool (Mihuta-Grimm et al., 1990). In all treatments, fresh weight of seedlings was inversely correlated with the severity of Fusarium crown and root rot (Figs. 1-5), supporting previous observations for this disease (Duffy and Défago, 1997; Jones et al., 1991; Woltz et al., 1992). Windborne and insect-transmitted spores were not a factor in this study, because noninoculated plants that were placed in the greenhouse (but not included in the experiments) remained disease-free.

Nitrogen form had a major influence on the severity of Fusarium crown and root rot and on growth of tomato seedlings in a soilless rockwool system (Fig. 1). Increasing concentrations of nitrate- $\mathrm{N}$ reduced disease and improved plant growth in comparison with ammonium forms. Ammonium sulfate and ammonium chloride gave similar responses, implicating $\mathrm{NH}_{4}^{+}$as the deleterious component (Fig. 1). Ammonium nitrate has been reported to either have no influence on Fusarium diseases or to increase disease just as ammoniumN (Jones et al., 1989; Schneider, 1985). While this was generally true for Fusarium crown and root rot, by testing a range of concentrations we were able to observe that at low concentrations (10 to $\left.100 \mathrm{mg} \cdot \mathrm{L}^{-1} \mathrm{~N}\right)$, ammonium nitrate reduced disease in a fashion similar to nitrate-N (Figs. 1D, 2D). However, the negative influence of the $\mathrm{NH}_{4}^{+}$ion became evident at concentrations above $125 \mathrm{mg} \cdot \mathrm{L}^{-1} \mathrm{~N}$ (Figs. 1D, 2D). At higher concentrations, seedlings may have had insufficient available carbohydrates to convert the excess ammonium, which is toxic for tomato seedlings (Woltz et al., 1992), to nontoxic amino acids (Pate, 1973).

Nitrates have long been recognized for reducing seedling disease caused by Rhizoctonia solani (Huber and Watson, 1974); however, contradictory results have been reported for Fusarium crown and root rot. MihutaGrimm et al. (1990) reported that nitrogen supplied as a $20 \mathrm{~N}-20 \mathrm{P}-20 \mathrm{~K}$ fertilizer had no effect on growth of $F$. oxysporum f.sp. radicis-lycopersici in rockwool compared to nonfertilized treatments. Jarvis and Thorpe (1980) found no effect of nitrogen form (total $\mathrm{N}$ applied was not specified) on disease or yield when adequate lime was provided to negate potential $\mathrm{pH}$ effects. Indeed, a differential effect of nitrogen form on $\mathrm{pH}$ is a major mechanism of action for suppression of many soilborne pathogens (Huber and Watson, 1974). In contrast, Woltz et al. (1992) reported that nitrate- vs. ammonium-N (each at $225 \mathrm{mg} \cdot \mathrm{L}^{-1}$ $\mathrm{N})$ reduced severity of crown and root rot without affecting soil $\mathrm{pH}(\mathrm{pH} 4.81$ and 4.85, respectively). Similarly, we observed no effect of nitrogen fertilization (or any other mineral amendment) on $\mathrm{pH}$ of the hydroponic solution. In both studies, though, only $\mathrm{pH}$ of
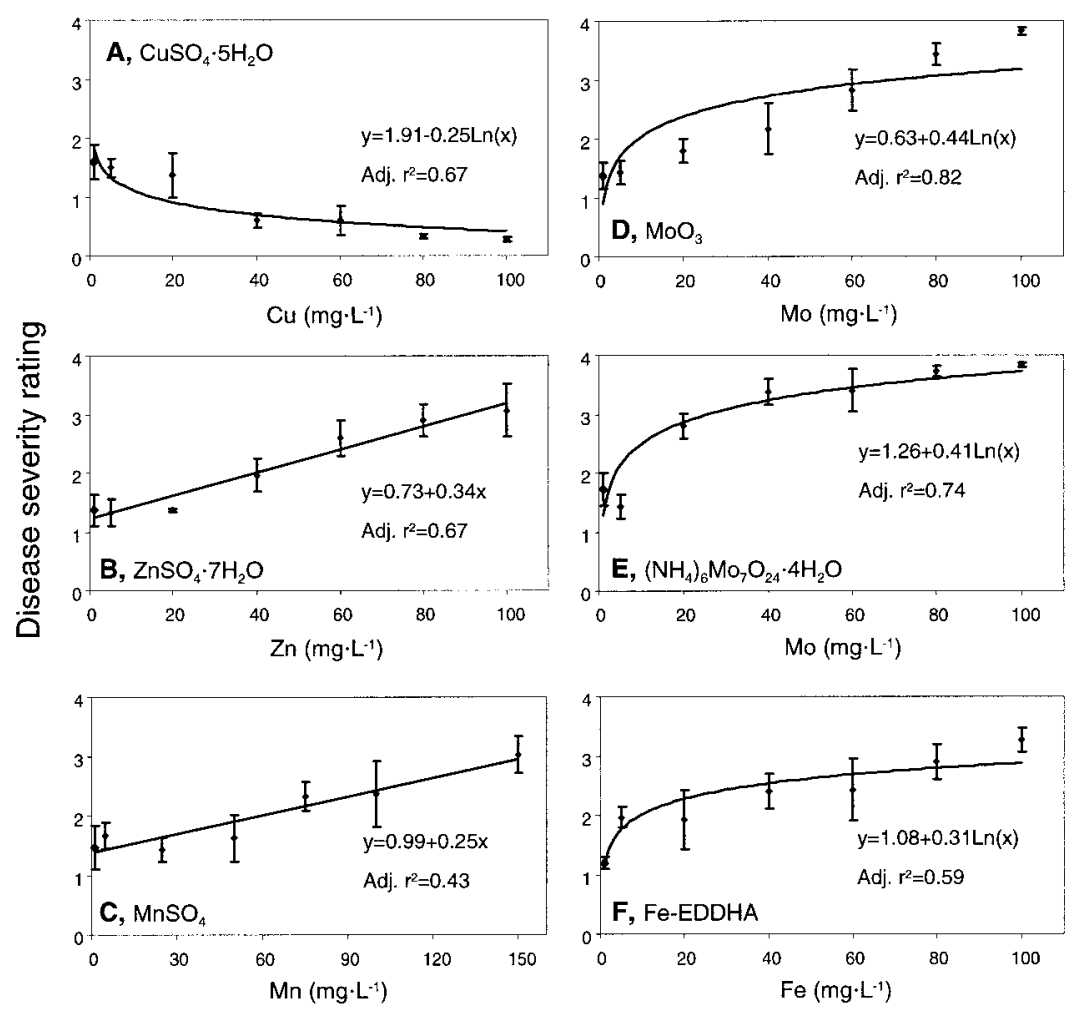

Fig. 4. Influence of micronutrients on the severity of Fusarium crown and root rot of tomato. Amendments of (A) $\mathrm{CuSO}_{4} \cdot 5 \mathrm{H}_{2} \mathrm{O}$; (B) $\mathrm{ZnSO}_{4} \cdot 7 \mathrm{H}_{2} \mathrm{O}$; (C) $\mathrm{MnSO}_{4}$; (D) $\mathrm{MoO}_{3}$; (E) $\left(\mathrm{NH}_{4}\right)_{6} \mathrm{Mo}_{7} \mathrm{O}_{24} \cdot 4 \mathrm{H}_{2} \mathrm{O}$; or $(\mathbf{F}) \mathrm{Fe}$ EDDHA were provided at planting. Values represent the means per plant in three trials. Adjusted regression coefficients and line derivations were significant at $P \leq 0.0008$. Vertical bars represent \pm standard error of the mean.
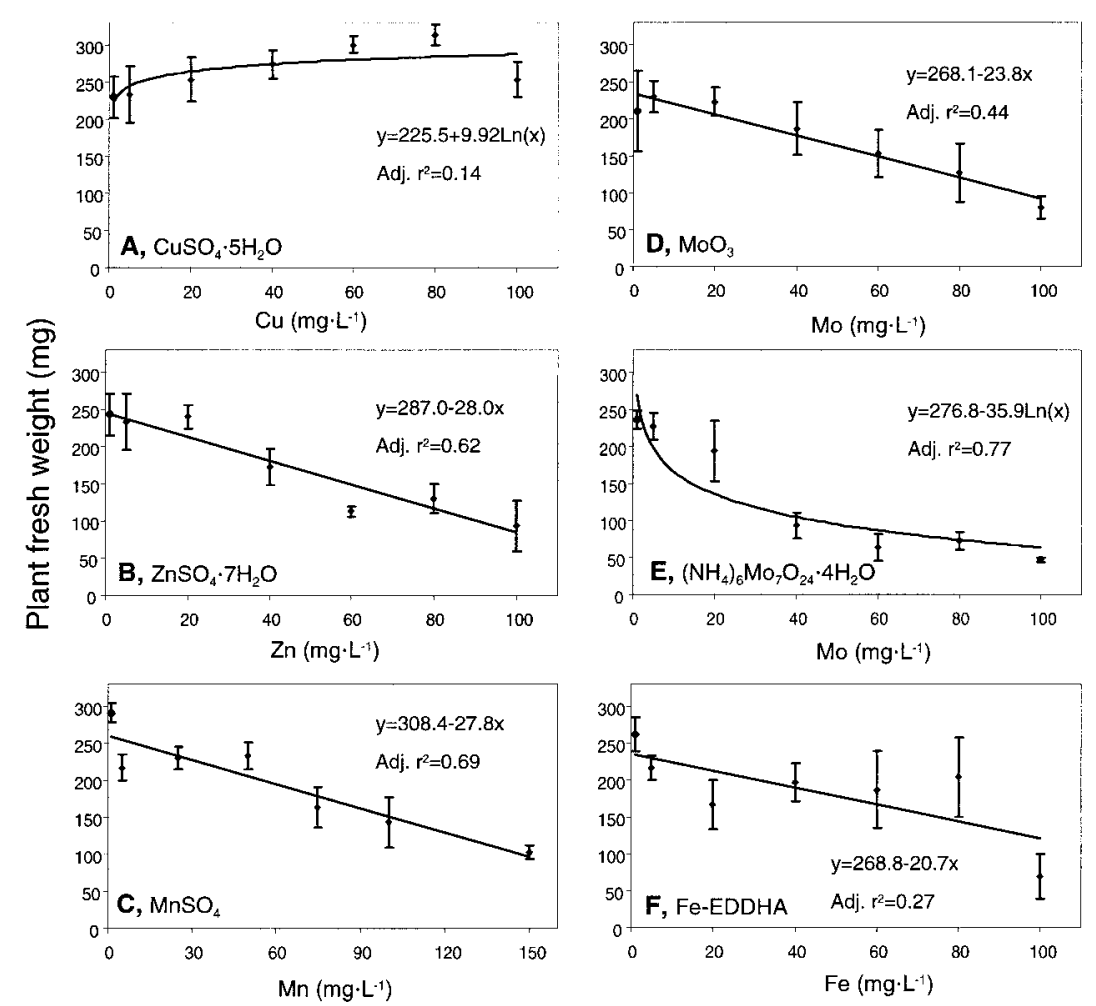

Fig. 5. Influence of micronutrients on tomato seedling growth after 2 weeks in rockwool infested with Fusarium oxysporum f.sp. radicis-lycopersici. Amendments of (A) $\mathrm{CuSO}_{4} \cdot 5 \mathrm{H}_{2} \mathrm{O} ;(\mathbf{B}) \mathrm{ZnSO}_{4} \cdot 7 \mathrm{H}_{2} \mathrm{O} ;(\mathbf{C})$ $\mathrm{MnSO}_{4} ;$ (D) $\mathrm{MoO}_{3}$; (E) $\left(\mathrm{NH}_{4}\right)_{6} \mathrm{Mo}_{7} \mathrm{O}_{24} \cdot 4 \mathrm{H}_{2} \mathrm{O}$; and (F) Fe-EDDHA were provided at planting. Values represent the means per plant in three trials. Adjusted regression coefficients and line derivations were significant at $P \leq 0.0007$ for all except $\mathbf{A}$ and $\mathbf{F}$, where $P=0.0504$ and 0.0091 , respectively. Vertical bars represent \pm standard error of the mean. 
the bulk media was measured and possible localized $\mathrm{pH}$ effects in the rhizosphere where disease actually occurs cannot be excluded (Smiley, 1975). Another possible factor may be total calcium concentrations, which are increased with liming and with calcium nitrates as used in our study and that of Woltz et al. (1992). They found that all treatments that increased calcium content also reduced disease. While adequate calcium in tomato tissues appears to be important for resistance to cell-wall-degrading enzymes (e.g., polygalacturanose) produced by Fusarium sp., it is generally considered a minor factor in controlling disease (Jones et al., 1989).

Sodium phosphate increased disease severity and reduced tomato growth (Fig. 3). Similar results with various phosphorus forms have been reported for wilt diseases caused by related formae speciali (Jones et al., 1989), and this has been attributed in part to the enhanced uptake of calcium (Jarvis, 1992). While possible effects of sodium cannot be excluded, exhaustive studies with other Fusarium diseases [i.e., celery yellows (Schneider, 1985) and asparagus wilt (Elmer, 1992, 1995)] revealed no influence of the $\mathrm{Na}^{2+}$ ion. Magnesium sulfate fertilization had absolutely no effect on Fusarium crown and root rot at concentrations up to $250 \mathrm{mg} \cdot \mathrm{L}^{-1} \mathrm{Mg}$ (Fig. 3). To our knowledge, this is the first examination of magnesium on $F$. oxysporum independent of the $\mathrm{Cl}^{2+}$ ion. Previous work has demonstrated that fertilization with $\mathrm{MgCl}_{2}$ increased wilt caused by $F$. oxysporum formae speciali on tomato (Jones et al., 1989) and celery (Schneider, 1985). In these studies, $\mathrm{Cl}^{2+}$ and not $\mathrm{Mg}^{2+}$ was suspected to be the problematic ion, a conclusion that is further supported by our results.

Copper sulfate effectively reduced disease severity (Fig. 4) and improved tomato growth (Fig. 5) at concentrations above $20 \mathrm{mg} \cdot \mathrm{L}^{-1} \mathrm{Cu}$. This is not surprising, considering the historical use of $\mathrm{Cu}^{2+}$ as a broad-spectrum fungicide (Schumann, 1991). No phytotoxicity was observed, even at the highest concentrations tested. In contrast, all other micronutrients tested aggravated disease (Fig. 4) and stunted growth (Fig. 5). Zinc and manganese increased disease at concentrations above 40 and 50 $\mathrm{mg} \cdot \mathrm{L}^{-1}$, respectively. Molybdenum increased disease at concentrations of $20 \mathrm{mg} \cdot \mathrm{L}^{-1}$ and above. Ammonium molybdate (Fig. 4E) was more conducive to disease than molybdenum oxide (Fig. 4D), perhaps because of the additive influence of the $\mathrm{NH}_{4}^{+}$ions. Iron added as Fe-EDDHA increased disease at concentrations of just $5 \mathrm{mg} \cdot \mathrm{L}^{-1}$ and greater, with only slight further increases until over $80 \mathrm{mg} \cdot \mathrm{L}^{-1}$ (Fig. 4F). We found no evidence for induction of host defenses by zinc, iron, or manganese, as suggested by Mandal and Sinha (1992). Plants supplied with zinc or ammonium molybdate at $33 \mathrm{mg} \cdot \mathrm{L}^{-1}$ exhibited no signs of toxicity in the absence of the pathogen (Duffy and Défago, 1997). However, node length declined with higher concentrations, suggesting that phytotoxicity as well as increased disease possibly contributed to reductions in fresh weight (Fig. 5). While excessive concen- trations are uncommon in agricultural soils and hydroponics, their availability can be increased under certain conditions, such as acidification. Incidentally, acidic $\mathrm{pH}$ also favors crown and root rot (Woltz et al., 1992). Inert materials such as rockwool tend to reduce plant sensitivity to minerals (Jarvis, 1992). Plants may also be exposed to elevated mineral concentrations applied to improve the beneficial activity of biological control strains of Pseudomonas fluorescens (Duffy and Défago, 1997). Results of our study facilitate the development of such microbe-mineral fertilizer treatments with minimal adverse side effects on the host plant, information that has been lacking. They also accentuate the need to develop methods for more efficient delivery of potentially phytotoxic minerals.

Exactly how mineral nutrients influence disease is uncertain, but effects on pathogen activity and host susceptibility are probably involved. Fusarium oxysporum has a relatively high requirement for micronutrients (Jones et al., 1989). Concentrations of zinc, iron, manganese, and other metals above those typically found in soil and nutrient solutions stimulate fungal growth and sporulation (Duffy and Défago, 1997; Jones et al., 1989). The profile of secondary metabolites produced by the pathogen, including phytotoxic compounds like fusaric acid, is also altered (Duffy and Défago, 1997; Egli, 1969). Nitrates inhibit both sporulation and spore germination, while ammonium has the opposite effect (Jones et al., 1989). Fertilization with nitrate-N decreases the sensitivity of tomato to fusaric acid, a phytotoxin produced in infected plants by Fusarium oxysporum (Barna et al., 1983). Susceptibility of tomato to fungal attack is increased by zinc, in part because zinc raises the sugar level in plant tissues (Jarvis, 1992). Host susceptibility can also be altered by interactions between minerals, particularly at elevated concentrations, which impact the availability of other nutrients. For example, ammonium-N interferes with the uptake of nitrates and potassium, which in turn stimulates chloride uptake, leading to increased susceptibility of tomato to $F$. oxysporum f.sp. lycopersici (Jarvis, 1992). Disease suppression with minerals has also been attributed to the stimulation of indigenous populations of antagonistic microorganisms in the soil and rhizosphere (Elmer, 1995; Engelhard, 1989). While this is generally not relevant to hydroponics, recent work indicates that minerals can be exploited to improve the beneficial activity of introduced biocontrol agents in soilless culture (Duffy and Défago, 1997).

Our results build on those of Woltz et al. (1992) and provide a foundation for developing a control strategy based on plant nutrition. Such an approach has been successfully applied to manage other Fusarium diseases (Jarvis, 1992; Jones et al., 1989). Mineral nutrient effects on crown and root rot of tomato caused by $F$. oxysporum f.sp. radicislycospersici were similar to those reported for other formae speciali, which reflects the adaptability of control strategies for various Fusarium diseases. It further suggests biologi- cal similarity of these pathogens and/or similar responses of diverse hosts to these fungi. Fusarium crown and root rot, however, is not the only problem threatening hydroponically grown tomato, and nontarget effects of certain mineral nutrients on other diseases need to be considered. A prominent example, nitrate-N, which reduced crown and root rot, increases the severity of economically devastating diseases caused by Pythium and phytopathogenic bacteria (Stanghellini and Rasmussen, 1994). Integrating mineral nutrients with newly developed resistant cultivars, biocontrol agents, and/or fungicides used at reduced, nonphytotoxic concentrations may enhance the level and spectrum of disease control.

\section{Literature Cited}

Barna, B., A.R.T. Sarna, and Z. Király. 1983. The influence of nitrogen nutrition on the sensitivity of tomato plants to culture filtrates of Fusarium and to fusaric acid. Physiol. Plant Pathol. 23:257263.

Bochow, H., S. Dolej, I. Fischer, and M. Alemayehu. 1996. Modes of action in biocontrolling fungal seedling and root rot diseases by Bacillus subtilis, p. 99-108. In: C. Alabouvette (ed.). Biological and integrated control of root diseases in soilless cultures. IOBC wprs Bul. vol. 19.

Duffy, B.K. and G. Défago. 1997. Zinc amendment improves the biocontrol of tomato crown and root rot by Pseudomonas fluorescens and represses the production of pathogen metabolites inhibitory to bacterial antibiotic biosynthesis. Phytopathology 87:1250-1257.

Egli, T.A. 1969. Untersuchungen über den Einfluss von Schwermetallen auf Fusarium lycopersici Sacc. und den Krankheitsverlauf der Tomatenwelke. J. Phytopathol. 66:223-252.

Elmer, W.H. 1992. Suppression of Fusarium crown and root rot of asparagus with sodium chloride. Phytopathology 82:97-104.

Elmer, W.H. 1995. The association among Mnreducing bacteria and sodium chloride applications in the suppression of Fusarium crown and root rot of asparagus. Phytopathology 85:14611467.

Engelhard, A.W. (ed.). 1989. Soilborne plant pathogens: Management of diseases with macro- and microelements. APS Press, St. Paul, Minn.

Erb, W.A. and R.C. Rowe. 1992. Screening tomato seedlings for multiple disease resistance. J. Amer. Soc. Hort. Sci. 117:622-627.

Gillespie, D.R. and J.G. Menzies. 1993. Fungus gnats vector Fusarium oxysporum f.sp. radicislycopersici. Ann. Appl. Biol. 123:539-544.

Hartman, J.R. and J.T. Fletcher. 1991. Fusarium crown and root rot of tomatoes in the UK. Plant Pathol. 40:85-92.

Heremans, B. 1996. Development of a rapid method for screening the resistance of tomato plants to Fusarium oxysporum f.sp. radicis-lycopersici. Med. Fac. Landb. Toeg. Biol. Wetensch. Univ. Gent 61(2A):337-341.

Huber, D.M. and R.D. Watson. 1974. Nitrogen form and plant disease. Annu. Rev. Phytopathol. 12:139-165.

Jarvis, W.R. 1988. Fusarium crown and root rot of tomatoes. Phytoprotection 69:49-64.

Jarvis, W.R. 1992. Managing diseases in greenhouse crops. APS Press, St. Paul, Minn.

Jarvis, W.R. and H.J. Thorpe. 1980. Effects of nitrate and ammonia nitrate on severity of fusarium foot and root rot and on yield of greenhouse tomatoes. Plant. Dis. 64:309-310.

Jarvis, W.R. and H.J. Thorpe. 1981. Control of 
Fusarium foot and root rot of tomato by soil amendment with lettuce residues. Can. J. Plant Pathol. 3:159-162.

Jones, J.P., A.W. Engelhard, and S.S. Woltz. 1989. Management of Fusarium wilt of vegetables and ornamentals by macro- and microelements, $\mathrm{p}$. 18-32. In: A.W. Engelhard(ed.). Soilborne plant pathogens: Management of diseases with macroand microelements. APS Press, St. Paul, Minn.

Jones, J.B., J.P. Jones, R.E. Stall, and T.A. Zitter (eds.). 1991. Compendium of tomato diseases. APS Press, St. Paul, Minn.

Komada, H. 1975. Development of a selective medium for quantitative isolation of Fusarium oxysporum from natural soils. Rev. Plant Prot. Res. 8:114-125.

Littell, R.C., R.J. Freund, and P.C. Spector. 1991. SAS system for linear models, 3rd ed. SAS Institute, Cary, N.C.

Louter, J.H. and L.V. Edgington. 1990. Indications of cross-protection against fusarium crown and root rot of tomato. Can. J. Plant Pathol. 12:283288.

Mandal, N.C. and A.K. Sinha. 1992. An alternative approach for the chemical control of Fusarium wilt of tomato. Indian Phytopathol. 45:194198.

Mihuta-Grimm, L., W.A. Erb, and R.C. Rowe. 1990. Fusarium crown and root rot of tomato in greenhouse rock wool systems: Sources of inoculum and disease management with benomyl. Plant Dis. 74:996-1002.

M'Piga, P., R.R. Bélanger, T.C. Paulitz, and N. Benhamou. 1997. Increased resistance to Fusarium oxysporum f.sp. radicis-lycopersici in tomato plants treated with the endophytic bacterium Pseudomonas fluorescens strain 6328. Physiol. Mol. Plant Pathol. 50:301-320.

Pate, J.S. 1973. Uptake, assimilation and tranport of nitrogen compounds by plants. Soil Biol. Biochem. 5:109-119.

Rowe, R.C. and J.D. Farley. 1981. Strategies for controlling Fusarium crown and root rot in greenhouse tomatoes. Plant Dis. 65:107-112.

Schneider, R.W. 1985. Suppression of Fusarium yellows of celery with potassium, chloride, and nitrate. Phytopathology 75:40-48.

Schumann, G.L. 1991. Plant diseases: Their biology and social impact. APS Press, St. Paul, Minn.

Sivan, A., O. Ucko, and I. Chet. 1987. Biological control of Fusarium crown rot of tomato by Trichoderma harzianum under field conditions. Plant Dis. 71:587-592.

Smiley, R.W. 1975. Forms of nitrogen and the $\mathrm{pH}$ in the root zone and their importance to root infections, p. 55-62. In: G.W. Bruehl (ed.). Biology and control of soil-borne plant pathogens. APS Press, St. Paul, Minn.

Stanghellini, M.E. and SL. Rasmussen. 1994. Hydroponics: A solution for zoosporic pathogens. Plant Dis. 78:1129-1138.

Sugahara, S. and Y. Sakurai. 1991. Breeding of "Sanpou First 60": A new tomato cultivar resistant to Fusarium crown and root rot. Res. Bul. Aichi-Ken Agr. Res. Ctr. 23:163-170.

Woltz, S.S., J.P. Jones, and J.W. Scott. 1992. Sodium chloride, nitrogen source, and lime influence Fusarium crown rot severity in tomato. HortScience 27:1087-1088.

Ziegler, H. 1983. Die Nährstoff und ihr Umsatz in der Pflanze. 2. Verfügbarkeit der Nährelement, p. 334-336. In: E. Strassburger, F. Noll, H. Schenk, and A.F.W. Schimper (eds.). Lehrbuch der Botanik. Gustav Fischer Verlag, Stuttgart and New York. 